\title{
Verbal Categories of Tae' Language and Cognitive Models of Luwu People
}

\begin{abstract}
Magfirah Thayyib
Institut Agama Islam Negeri Palopo

Corresponding author Email: magfirah_thayyib@iainpalopo.ac.id

ABSTRACT

Different language categories result in different ways of thinking. This research aims at analyzing the verbal categories of Tae' language and the pertinent cognitive models of Luwu People. It is an attempt to have a philosophical understanding of Tae' language as one of the local languages in South Sulawesi. This research used the descriptive-qualitative method. The data of the research were obtained from native speakers of Tae' language in Larompong District, Luwu Regency. The data were gathered through interviews with recording and note-taking techniques. The data were then transcribed and translated into English. The data were analyzed using the categories of Hopi language by Whorf and the theories of cognitive psychology by Sternberg, namely the theories of perception and memory. Tae' language has several verbal categories of assertion, mode, status, and modality. The categories reveal the complexity of constructive perception of Luwu people and their high use of memory.
\end{abstract}

Keywords: verbal categories, Tae’ language, cognitive models, Luwu people

\section{INTRODUCTION}

The relation between language and thought has long been an intrigued issue. Some experts argue that the way people think in a culture determines the way they communicate with others. Conversely, some other experts believe that the language used by certain people in communication is the one that determines the way they view the world. It is supported by Linguistic Relativity from the Sapir-Whorf hypothesis which states that a language structure used by people influences the way they think and behave Wedasuwari [1].

Related to Linguistic Relativity, one of the ideas of language philosophy is that how language structure influences the way of thinking. According to Asoulin [2], an alternative construal of language that sees it as an instrument of thought is most notably manifested in the philosophy of language and linguistics. How language influences thought is clarified by Sternberg [3] that our thoughts and our language interact in myriad ways; language facilitates thought and it even affects perception and memory. "Perception is the set of processes by which we recognize, organize, and make sense of stimuli in our environment" [3]. "Memory is how we draw on our knowledge of the past to use this knowledge in the present" [3].
Considering the philosophical idea of Linguistic Relativity, while ruling out Universal Grammar, language structure and category cannot prevail universally indeed. There should be unique cognitive models rather than cognitive commonalities among different language users. Each language categorizes the world differently. Different language categories result in different ways of thinking. Then, linguistic categories reflect the cognitive models of the speakers. Yoshimura in Sutedi [4] asserted that the cognitive system in linguistics is all the activities of human thought in understanding and elucidating every experience subjectively.

There have been few pieces of research that studied the way people think from their language expressions. Dardjowidjojo [5] explored several phenomena which indicate the way the Indonesian speakers think. Sudaryat [12] described the mindset of Sundanese people in their language expressions examined from psycho-pragmatic aspects. Rahardian [6] described the Javanese speakers in the Semarang way of thinking by conceptualizing metaphorical expressions and their cognitive process. There have been also ample researches on Tae' language structure eg. Ibrahim, [7]; Hidayah, [8]; Pujiati \& Rusdiansyah [9]. A study drawing a philosophical idea of Tae' language's 
structure particularly the cognitive models of the speakers would be fruitful as well.

This paper presents some verbal categories of Tae' language to have an alternative structural understanding of the language. It is expected that this analysis can give pieces of philosophical ideas of Tae' language and new distinctive features of Luwu culture. The presentation in this paper simply follows the flow of Whorf's article "Some Verbal Categories of Hopi" Carroll, [10] and directly puts Tae' verbal categories based on Hopi's categories. Then, the cognitive models of Luwu people who speak Tae' language are discussed accordingly. Hopi is an Indian language considered exotic by Whorf because of its distinct categories.

Tae' itself is one of the local languages in Luwu area, South Sulawesi, Indonesia. Based on the Ethnologue data, the number of Tae' speakers is 250.000 and increasing Lewis, [11]. It is used from Larompong district in Luwu Regency until Masamba in Luwu Utara with some other scattered pockets. To be noticed that the basic structure of Tae' is verb+subject, Tandea-na 'hungry+I' for 'I am hungry' or Kumande-na 'eat $+\mathrm{I}$ ' for 'I am eating'. Still, there are some other structural variations like subject+verb+ $i$ (object successor particle), Ku-kande-i 'I+eat+that object.' This variation exists whenever the object is recognized, then the verb kumande changes into kande.

\section{METHOD}

This research used the descriptive-qualitative method. The data of the research were obtained from native speakers of Tae' language in Larompong District, Luwu Regency. The data were gathered through interviews with recording and note-taking techniques. The data were then transcribed and translated into English. The data were analyzed using the categories of Hopi language by Whorf and the theories of cognitive psychology by Sternberg, namely the theories of perception and memory. The data of Tae' verbal categories in use/in utterances were classified as either constructive perception or direct perception Sternberg [3]. The extent of the utterances' memory used was also determined.

\section{ANALYSIS}

Four generic verbal categories of Hopi are referred to in discussing the ones of Tae' in this part, namely assertion, mode, status, and modality.

\subsection{Assertion}

Hopi verbs have three assertions: Reportive (zero forms), Expective (suffix $-n i$ ), Nomic (suffix $-\eta^{w} i$ ). Tae' seems to have such assertions but simpler ones. Assertions in Hopi do not refer to time or duration. They distinguish three kinds of information. Tae' assertions also do not merely refer to time or duration. They sometimes refer to the subject of the verb at the same time. Several particles in Tae' designate more than one function.

\subsubsection{Reportive}

The reportive in Tae' refers to a present continuous or perfect continuous event. There is no assertion in Tae' to report a past event. Adverb of time is directly added to a sentence to have a past sense, e.g. sammai 'yesterday'. Tae' may report the event in the first and third person. The event of the second person belongs to the imperative sentence. For the third person subject, the speaker of reportive can either see the event directly or only know that the event happened/happening. The listener's perspective has no deal with that reportive.

$\begin{array}{ll}\text { Mallai }-\underline{m o} & \underline{\text { I have been running }} \\ \text { Mallai }-\underline{n a} & \underline{\text { I am running }} \\ \text { Mallai }-\underline{m i} & \underline{\text { He has been running }} \\ \text { Mallai }-\underline{\text { mikang }} & \underline{\text { He is running }} \\ \text { Mallai }-\underline{\text { ke hang }} & \underline{\text { We are running }}\end{array}$

\subsubsection{Expective}

The expective declares an expectation or anticipation of a situation. It is translated by English future, 'is going to', or 'begins to.' The assertion of expective in Tae' has nothing to do with time as such, an expectant attitude may be projected into an account of past events. The expective in Tae' is made by simply putting the prefix $l a$ - to the verb. The meaning may be 'will' or 'will begin to.'

$\begin{array}{ll}\underline{\text { La-mallaimo }} & \text { I will begin to run } \\ \underline{\text { La}- \text { mallaina }} & \text { I } \underline{\text { will run }} \text { run } \\ \underline{\text { La}- \text { mallaimi }} & \text { He will begin to run } \\ \underline{\text { La-mallaii }} & \text { He will run }\end{array}$

\subsubsection{Nomic}

The nomic does not declare any particular situation, but offers the statement as a general truth, e.g. English 'she writes poetry, rain comes from the clouds.' In Tae', the nomic structure is the same as the reportive structure of a present continuous event. Their different meaning can be noticed by the context of the conversation.
mappa'guru teach
Apa tajama (te')? Mappaguruna
What are you doing now? I am teaching
Apa tajama(jama) lako te'? Mappaguruna
What is your job now? I am a teacher

According to the theory of perception by Sternberg, the reportive assertion in Tae' language reveals that Luwu people may have both constructive perception and direct perception. They can construct the stimulus perceived using prior knowledge, contextual information, and sensory information. They can also perceive the sensory input to have and share all the 
information needed. This cognitive model is somewhat similar to the mindset of Javanese speakers in Semarang in that they use their perception and prior experiences Rahardian, [6]. The reportive and expective assertions in Tae' language always make use of memory to draw on experiences in various moments to use that information in the present. It can be implied that through their assertion structure, Luwu people may have flexible use of perception and high use of memory.

\subsection{Mode}

Mode is the generic category of the system by which is denoted the nature of the mingled discreteness and connection between a sentence (clause) and the sentence (clause) which follows or precedes it. Independent mode implies that the sentence is detached from others, though it is possible to relate such sentence by paratactic connectives like English 'and'. But the Hopi shows a great liking to hypotactic constructions. These employ six mutually exclusive dependent modes denoted by suffixes placed after the assertion of suffix.

Tae' also has such a mode category but a simpler one. Tae' modes seem to be independent ones because the particles are not directly placed in the verb. The meaning of Tae' sentences implied by the use of Tae' modes is also simpler. It implies the meaning of the sentences (clauses) purely and added by the meaning of the mode employed.

\subsubsection{Conditional}

The conditional mode in Tae' is stated by the use of 'ke', 'ake', or 'yake' (lexical variation) which means 'when, if.' The place of ' $k e$ ' is the same as the English 'if' that is at the beginning of the if clause. The position if clause and main clause in Tae' conditional are also changeable. Both clauses of Tae' conditional usually designate nomic form. But, expective form can be used in one of the clauses or both of them.

$((Y)$ a)ke sulei lako banua, natiroi to' salu

When he goes home, he sees the river

$((Y) a) k e$ sulei lako banua, lanatiroi to' salu

When he goes home, he will/want to see the river

\subsubsection{Correlative}

Correlative mode in Tae', just like in English, is shown by the use of reason and result linking words, nasaba (probably from Indonesian sebab) or appa for 'because,' 'since,' and 'as'; there is no specific linking word for 'for' in Tae'. The correlative mode in Tae' can have reportive, expective, and nomic forms by the adjustment of the verb particle.

Appa' sulei lako banua, natiroi to' salu

Because/since/as he goes home, he sees the river

\subsubsection{Concursive}

Tae' concursive mode is signed by time linking words, na for 'while, and,' tonna for 'as, at the same time.' Tae' concursive mode can also have three forms.

Tonna sulei lako banua, natiroi to' salu

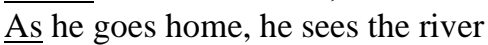

Menarii na sumengo He danced and sang

\subsubsection{Sequential}

Tae' sequential mode is signed by time linking phrases, tonna purami for 'after,' na mane for 'and then'. It is just like the extension of Tae' concursive mode.

Tonna lattumi jio banua, natiroi to' salu

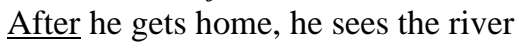

Menarii na mane sumengo

He danced and then sang

\subsubsection{Agentive}

The agentive mode in Tae' recognizes only English 'who, which' not 'whom.' 'Who, which' use the same agentive word in Tae' with several lexical variations, to', to'o, yato', and yato'o.

Yato' muane sule lako banua, tiroi salu

The man who went home saw the river

Kutiro(i) - yato' muane sule lako banua

I saw - the man who went home

\subsubsection{Transrelative}

Transrelative mode is general relatedness bridging a difference of subject in two clauses. It has no English equivalent; no Tae' equivalent as well. In Hopi, the previous five modes refer to the condition in which the subject of both clauses is the same. While in Tae', those five modes can refer to the condition in which the subject in the first clause is different from the subject in the second clause. So, it can cover the absence of transrelative in Tae'.

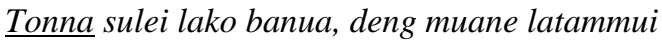

When he goes home, a man will meet him

$\underline{\text { Appa }^{\prime}}$ menarii to' pea muane, jaji sumengoi to' pea

bene

Since the boy dance, therefore the girl sang

Despite its simplicity and independence in representation, the mode of Tae' language is complex because it meets various linguistic discreteness and connection. Knowledge representation is also a part of perception Sternberg, [3]. Thus, the perception of Luwu people through their language mode can be said as complex which requires greater memory use. The perception itself is mostly constructive. The logic on mode expression is constructed mainly based on sensory and auditory perceptions related to time and place. 


\subsection{Status}

The status categories have been named affirmative, negative, interrogative, and definitive. In Tae', various basic structures of affirmative status form have been shared in the introduction and previous verbal categories. The rest statuses are discussed as follow:

\subsubsection{Negative}

Negative status in Tae' is made by the use of the negation word tae'. The basic pattern of Tae' negative statement is negationword+subjectparticle+verb+object.

$\begin{array}{ll}\text { Tae' nakumande } & \text { He does not eat } \\ \text { Tae' kuissengngi } & \text { I do not know (about) it } \\ \underline{\text { Tae' namaballo }} & \text { It is not good } \\ \text { Tae' nadeng sule } & \underline{\text { He never went (home) }}\end{array}$

\subsubsection{Interrogative}

Yes-no-question in Tae' is formed by the addition of the word raka usually at the end of the sentence or simply the change of intonation of affirmative status. Tae' also has a wh-question with several question words that should be placed at the beginning of the sentence.

\begin{tabular}{|c|c|}
\hline La-mallaii? (raising intonation) & Will he run? \\
\hline La-mallaii raka? & Will he run? \\
\hline Enda sangangta? & What is your name? \\
\hline \multicolumn{2}{|c|}{ Umbananai banиатти? Where is your home? } \\
\hline Pirang $($ pi) nasule? $\quad$ When w & ill he come back? \\
\hline
\end{tabular}

\subsubsection{Indefinitive}

There is no specific particle or word as indefinitive marker status in Tae'. Still, it is possible to have such indefinitive status by using the affirmative and interrogative statuses at once.

\section{Mataku'na - apa lakajajiang?}

I wonder - what is coming?

Similar to the mode, the status of Tae' language discloses the complexity of constructive perception and memory use of Luwu people which is represented in a rather simple representation. Different forms and details of the perception of Luwu people may result in diminutive variations of the status expressions of Tae' language. The variations of the status expression in the negative and interrogative form, fortunately, have a clear pattern as can be seen in the examples.

\subsection{Modality}

There are eight modalities in Hopi that referred to discuss the modalities in Tae', they are:

\subsubsection{Quotative}

There are words or phrases in Tae' that are similar to quotative markers in Hopi like karebanna 'according to the story', nakua 'they/he/she say(s)', and kade' 'it is said. The last one is commonly used to emphasize that the speaker does not see the story or report shared; the speaker just quotes from others.

Kusa'ding ronnoi kade'

I heard (that) he fell down

\subsubsection{Inhibitive}

Hopi inhibitive modalizer is translated simply by 'cannot'. In Tae', 'cannot' is translated as tae' (subject) bela and tae' (subject) wadding.

Tae' nabela sule He cannot go home

Tae' kuwadding sule I cannot go home

\subsubsection{Potential}

The potential modality in Tae' is simply the opposite of the inhibitive modality. The word tae' is omitted and the subject particle is placed after the verb as Tae' basic sentence structure.
Nabelai sule
Waddingna sule
He can go home
I can go home

\subsubsection{Indeterminate}

Indeterminate modality indicates uncertainty corresponding to 'perhaps, possibly, maybe' in English. In Tae', indeterminate modality relates to potential modality since the word nabela and wadding can also mean 'perhaps, possibly, maybe'. Another word that has such meaning is kapang. It can be used together with nabela and wadding to have indeterminate emphasis.

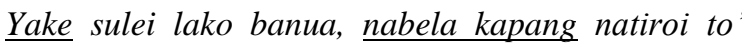
salu

When he goes home, he maybe sees the river

\subsubsection{Advisory}

There is no advisory modality in Tae'. To advise in Tae', simple and direct sentences can be used. Tae' does not have such a classy advisory modality of Hopi.

\subsubsection{Concessive}

There is also no concessive modality in Tae'. It is quite rare to say something with concessive modality even in a simple and direct sentence. But if English 'it seems that' is said as an independent concessive marker, then Tae' can say it with pada bang kimua.

\subsubsection{Necessitative}

Necessitative in Tae' has no specific modalizer. 'Necessarily, naturally, inevitably' can be said by the word parallu (from Indonesian perlu) and emphasized by the word inang 'really (have to).'

Inang parallui sule He really has to go home 


\subsubsection{Impotential}

It is difficult to find impotential expression in Tae'. Indeed, it is said that impotential modality is very difficult to express in our ways of thinking. But if English 'although' is said as an independent impotential marker, then Tae' can say it with namoi.

Some of the modality categories in Hopi do not exist in Tae' language. The existing categories of the modality still show constructive perception but it is not as complex as the previous three categories (i.e. assertion, mode, status). It can be implied from the independent words representing the modality in Tae'. This simple modality expression also relates to the regular use of memory which is, again, not as high as in the other verbal categories. The memory use occupied in the modality expression is rather accompanied by the subjectivity of the Luwu people. This minor fact confirms the statement of Yoshimura in Sutedi [4] that human elucidates an experience subjectively. It is also similar to one of the mindsets of Sundanese speakers namely subjectivity [12].

\section{CONCLUSION}

From the above analysis, we can see that several verbal categories in Hopi do not exist in Tae'. Then, some of them can only be said by independent expression of words or phrases and do not directly influence the verb in Tae'. However, we should not say that Hopi is superior to Tae'. Referring back to the idea that different language categories result in different ways of thinking, for sure, Tae' has its unique language categories that may not be found in Hopi. Some of them have been shared in the discussion of this paper.

The categories mostly reveal the complexity of constructive perception of Luwu people and their high use of memory. Surprisingly, many of the verbal categories in Tae' language are in simple and flexible form even if they represent complex thought. It may implicate that Luwu people can have complex constructive perceptions but they tend to have simple language representation. Predictably, the high use of memory in Tae' language does not mainly deal with the time details but with other multiple information that makes the expression represents complex thought. It is just like many Indonesian local languages that are indistinctive for time detail.

At last, it is suggested to have further study with more systematic quantitative assessment on a greater number of samples to have a finer pattern of the cognitive models from the language used. The comprehensive pattern of Tae' words categories along with the cognitive models of the speakers can be used as supporting material for culture and language learning in Luwu areas.

\section{REFERENCES}

[1] Wedasuwari, I. A. M., (2020). Kajian Literatur: Bahasa, Budaya, dan Pikiran dalam Linguistik Antropologi, Wacana, XX(1), 1-7.

[2] Asoulin, E. (2016). Language as an Instrument of Thought. Glossa: A Journal of General Linguistics, 1(1), 1-23.

[3] Sternberg, R. J. (2009). Cognitive Psychology. Belmont: Wadsworth.

[4] Sutedi, D. (2003). Pengenalan Pendekatan Linguistik Kognitif dalam Penelitian Bahasa. Paper presented in Temu Ilmiah Pendidikan dan Linguistik Bahasa Jepang II, 1-14.

[5] Dardjowidjojo, S. (2010). Bahasa dan Pola Berpikir Bangsa Kita. Linguistik Indonesia, 28(2), 105-112

[6] Rahardian, E. (2016). Pola Pikir Penutur Bahasa Jawa Dialek Semarang dalam Rubrik "Rame Kondhe" di Harian Suara Merdeka. Proceeding of International Seminar on Language Maintenance and Shift (LAMAS) 6, 254-258.

[7] Ibrahim, G. A. (2013). Tiga Tataran Ergativitas dalam Bahasa Tae'. Linguistik Indonesia, 31(1), $15-41$.

[8] Hidayah, A. M. N. (2017). Frasa dalam Bahasa Tae'. Sawerigading, 23(2), 195-204.

[9] Pujiati, T. \& Rusdiansyah. (2017). Kalimat Tanya Bahasa Bugis dan Bahasa Tae' (Kajian Analisis Kontrastif). Proceeding of Seminar Tahunan Linguistik Universitas Pendidikan Indonesia, 524529.

[10] Carroll, J. B. (1959). Language, Thought, and Reality: Selected Writings of Benjamin Lee Whorf. Cambridge: The MIT Press.

[11] Lewis, M. P. (2009). Ethnologue: Languages of the World, Sixteenth Edition. Dallas: SIL International.

[12] Sudaryat, Y. (2015). The Mindset of Sundanese People in Their Language Expressions. Indonesian Journal of Applied Linguistics, 5(1), 126-133. 